\title{
Ansvar for skade forårsaket av rein
}

\section{Fagfellevurdert artikkel}

\section{Av stipendiat Øyvind Ravna}

\begin{abstract}
Reineiere og bufeholdere har begge objektivt ansvar for skade deres dyr forårsaker. I praksis kan dette ansvaret arte seg ganske ulikt. Reindriftsloven er for tiden under revisjon, og lovutvalget har uttrykt at det erstatningsansvar som reindriftsloven stiller opp, er strengt og meget omfattende. I artikkelen sammenliknes ansvaret for reineiere og bufeholdere, samtidig som det pekes på ulikheter i regelverk og praksis som viser behov for en harmonisering. Det blir også påpekt at den lite påaktede regel i reindriftsloven § 26 om skjønn for å få vurdert gjerdeholdsadgang og -deling mellom reineier og grunneier, ikke er nyttet, noe som har ledet til at ansvaret for reinskade i praksis synes å ha blitt strengere enn forutsatt av lovgiver.
\end{abstract}

ØYVIND RAVNA ble cand. agric (jordskiftekandidat) ved NLH i 1987. Han har arbeidet som jordskiftedommer og jordskifterettsleder ved Finnmark jordskifterett. Han har nå permisjon fra jordskifteretten og er stipendiat ved Det juridiske fakultet, Universitetet i Tromsø.

\section{Problemstillinger}

Både reindrift og deler av bufeholdet er basert på at dyrene nytter utmarksbeite. For reindriftssamer er dette den eneste måten dyrene kan få sitt næringsbehov dekket på, mens det for bufeholdere er en av flere måter for å sikre dyrene føde. Selv om utmarksbeitets betydning for bufe er redusert de siste tiårene, er dette fortsatt helt nødvendig for småfeholdere. Rettsgrunnlaget for de to næringene er forskjellig. Mens reineiers beiterett er basert på en bruksrett tuftet på alders tids bruk, uavhengig av hvem som eier grunnen, kan bufeholders beiterett være basert på grunneierrett, på allmenningsrett eller på beiterettsservitutter. Felles for begge grupper er at de har vokteplikt med et korresponderende objektivt ansvar for skade forårsaket av dyrene. 
I praksis kan det objektive ansvaret være ganske ulikt for de to gruppene. Reindriftslovutvalget har gitt uttrykk for at «[d] et erstatningsansvar som reindriftsloven av 1978 oppstiller, er strengt og meget omfattende». ${ }^{1)}$ I relasjon til lovutvalgets uttalelse er det naturlig å reise spørsmål om reineiers erstatningsansvar etter reindriftsloven ${ }^{2)}$ er strengt i forhold til ansvaret ved bufehold. Jeg vil i det følgende sammenlikne reineiers og bufeholders erstatningsansvar. Utviklingen av reineiers ansvar over tid vil også bli sett på. Om det er sider ved reglene om reineiers erstatningsansvar som bør ses nærmere på ved en lovrevisjon, vil bli drøftet.

\section{SKADEANSVAR, VOKTEPLIKT OG GJERDEHOLD}

2.1 Dyreeiers ansvar for skade forårsaket av bufe og den delte gjerdeplikten Ved lov 16. mai 1860 om Jords Fredning ble husdyrholder gjort ansvarlig for den skade hans dyr forårsaket gjennom et objektivt ansvar for skade på naboeiendom. Samtidig fastsatte lovgiver at nabo kunne kreve at nabo skal delta i gjerdeholdet over innmark og mellom innmark og utmark, jf. $\$ 1$. Regelen gjaldt uavhengig av husdyransvaret og er omtalt som gjerdeholdstvang. ${ }^{3)}$ Dette lettet bufeholders vokteplikt, samtidig som den kunne gi seg utslag i redusert erstatningsansvar for beiteskade der jordeier forsømte sin del av gjerdeholdet, jf. $\$ 24$ bokstav c.

Det objektive ansvar som eier hadde for å vokte sine dyr etter lova av 1860, også kalt vokteplikten, ble videreført i lov 16. juni 1961 nr. 12 om ymse beitespørsmål (beiteloven) $\$ \$ 6$ og 7 . Den vilkårsløse regelen om gjerdeholdstvang over innmark og mot utmark ble imidlertid fjernet. I lov 5. mai 1961 om grannegjerde (ggl.) $\$ 7$ ble i stedet gjerdeplikt gjort betinget av nyttefor de tilstøtende eiendommer. ${ }^{4)}$ Regelen innebærer at dersom eiendommene samlet har større nytte enn kostnad av gjerdet, kan granne kreve

1) NOU 2001: 35 Forslag til endringer i reindriftsloven s. $183 \mathrm{sp.} \mathrm{1.} \mathrm{Utvalgets} \mathrm{mandat} \mathrm{var}$ avgrenset til endringer av reglene som regulerer styringen og forvaltningen av reindriften og interne forhold i reindriften, herunder den enkelte reineiers rettsstilling. Det har derfor ikke foreslått endringer av reglene om ansvar for reinskade.

2) Lov 9. juni $1978 \mathrm{nr} .45 \mathrm{om}$ reindrift (reinl.)

3) I Ot.prp.nr.16 (1959) Om lov om grannegjerde s. 13 sp. 1 uttales det om gjerdeholdstvangen at «hovudregelen [er] at grannane ... kan krevje halvt gjerdehald av kvarandre». Unntaket for gjerdeplikt ble gitt i gjerdeloven av $1860 \S 3$. At den ene nabo var jorddyrker mens den andre var dyreholder, fritok ikke førstnevnte for gjerdeplikt. Slik Axel Hærem, Gjerdehold mellom naboer (Oslo 1970) s. 66, som påpeker at husdyransvaret var uten betydning for gjerdeplikten.

4) Det kan og nevnes at loven er gjort deklaratorisk ( $\$ 1$ første ledd), slik at avtale om gjerdehold går foran loven. «Serlege rettshøve», altså etablerte gjerderettsforhold, kan også tilsidesette regelen i § 7 . 
gjerdehold av granne. Dette endres ikke av at den ene eiendom kun har begrenset nytte, mens den andre har stor nytte. Der gjerdeplikt foreligger, er utgangspunktet at hver nabo skal holde en halvpart av gjerdet. Dersom det blir urimelig, kan «gjerdehaldsskyldnaden delast mellom dei etter skjøn», jf. ggl. $₫ 8$ første ledd.

Gjerdehold kan også kreves mellom bruksrettshaver (f.eks. beiterettshaver) og grunneier, jf. ggl. \$ 11 første ledd. Der slik gjerdeplikt foreligger, skal kostnadene deles mellom dem som har nytte av gjerdet. Mislighold av gjerdeplikt kan betraktes som medvirkning til skade og dermed lede til reduksjon eller bortfall av erstatning der vokteplikten ikke er overholdt, jf. beiteloven $\$ 7$ annet ledd.

I RG 1981 s. 592 (Frostating) hadde A sluttet å vedlikeholde et gjerde mellom egen innmark og utmark. Dette medførte at sauene til B kom inn på innmark. A ble ved gjerdeskjønn pålagt vedlikehold av gjerdet. Skjønnet ble opphevet av herredsretten. Lagmannsretten stadfestet skjønnet da bruksrettsområde måtte likestilles med naboeiendom i grannegjerdelovens forstand, og uttalte at man i ggl. $\$ 11$ har ment å ta hensyn til tilfeller der eiendomsrett og bruksrett ikke er på samme hånd. Etter regelen kan beiterettshavere «kreve eller forpliktes til gjerdehold ved siden av grunneieren for den del av eiendommen som beiteretten gjelder». Det ble bl.a. vist til Rådsegn $1 \mathrm{~s}$. 14, hvor det ble lagt til grunn at beiterettsområde skulle likestilles med naboeiendom. Det var forutsatt at regelen også skulle gjelde der innmarkseieren var grunneier i beiterettsområdet. «Dersom man ikke kunne pålegge gjerdetvang i disse tilfellene, ville loven ikke nå sin hensikt slik bruks- og beiteforholdene ofte er i vårt land.»

Krav om at begge parter skal ha nytte av gjerdet før gjerdeplikt foreligger, holdt opp mot det objektive erstatningsansvaret i beiteloven, kunne formodentlig lede til økt ansvar for bufeholderen. Det kan jo lett hevdes at nytten av gjerdet må tilskrives eieren av dyrene som nødvendiggjør gjerdet. Med henvisning til forarbeidene har Hærem påpekt at «[d]et har neppe vært meningen med den nye gjerdeloven at det ikke skulle være noen gjerdeplikt eller at $B$ [dyreholderen] skulle være alene om gjerdeholdet $\mathrm{i}$ et slikt tilfelle». ${ }^{5)}$ Han viste videre til at etter tidligere lov var husdyransvaret uten betydning for gjerdeplikten, og at det ikke kan antas at man med de nye reglene har hatt til hensikt å gjøre noen forandring på dette punkt. Med henvisning til Sivillovbokutvalgets tilrådning konkluderte han med at «man nærmest [har] ment å la stå åpent spørsmålet om hvor stor den relative nytte av gjerdet må antas å være for husdyreieren som følge av ansvarsreglene, men man har tydeligvis ikke ment at han skal ansees å ha hele nytten.» ${ }^{6}$ En kan dessuten merke seg at Sivillovbokutvalget mente at nytten for jordbrukseiendom kunne ligge i at gjerdet hjalp til å holde beitedyr borte fra grannegrunn.

5) Hærem, op.cit. s. 66. 
Dette fikk tilslutning fra lovgiver. ${ }^{7)}$

Rettspraksis peker samme veg. I et overskjønn avholdt av Hadeland og Land herredsrett 3. november 1964 delte overskjønnet gjerdeholdet mellom eier av innmark som ikke holdt dyr, og tilstøtende allmenning som ble nyttet til beite. Overskjønnet ble stadfestet av Høyesterett i Rt. 1965 s. 1277. Fordeling av gjerdehold var imidlertid ikke gjenstand for anke. ${ }^{8}$ I dom i RG 1970 s. 22 opphevet Eidsivating lagmannsrett et overskjønn da nytte av gjerde for et boligselskap forelå både fordi det ville heve eiendommens verdi, og det ville være en klar markering av hvor grensene for eiendommen gikk. Leieboerne ble ansett som brukere etter ggl. $\$ 11$.

Nytten som er grunnlag for gjerdeplikten er også drøftet i NOU 1980: 49 s. 19. Her regnes unngått skade på avling som nytte. En kan særlig merke seg uttalelsen om at «[å] sleppe bry og uhugnad med å gjere slikt ansvar [for skade av beitende bufe] gjeldande i grannehøve, må reknast for ein nytteverknad av økonomisk karakter»."

\subsection{Reineiers ansvar for skade forårsaket av rein}

Grunnlaget for dagens erstatningsregler for skade forårsaket av rein kan sies å ha sitt opphav i «felleslappeloven». ${ }^{10)}$ I $\$ 9$ ble reineier pålagt vokteplikt og skadeansvar.

6) Slik også Mons Sandnes Nygard, Ting og rettar(Bergen 1974) s. 16o, som uttaler at det blir "for skjematisk å seia at heile nytta av gjerdehaldet ligg i at eigaren vert letta i tilsynet med dyra og slepp å koma i ansvar». Han viser til at flertallet i justiskomiteen (Innst. O. XIII (1960-61) s. 8) med henvisning til Rådsegn 1 (s. 20) hadde en slik grunngiving: «Dei nytteverknader som skal leggjast til grunn for utlikninga, er så mange og av så ulikt slag, at det $\mathrm{i}$ sume tilfelle vert sers vanskeleg å finna eit brukeleg sams mål eller grunnlag for samanlikninga mellom dei. Dette kunne lett føra til at skjønsavgjerdene kom til å gå på slump eller etter godtykke, og at like tilfelle fekk ulik avgjerd.»

7) Se hhv. Rådsegn 1 s. 13 sp. 2, Ot.prp. nr. 16 (1959) s. 14 sp. 1 og Innst. O. XIII (1960-61).

8) Overskjønnet er gjengitt etter Torgeir Austenå, Gjerde- og beitelov, med særlig vekt på gjerdeplikten, upublisert foredragsnotat (26 s.) for Frostating jordskiftedøme (Oppdal 1993). Se også Hærem, op.cit. s. 69-70.

9) NOU 1980: 49 Revisjon av gjerde-og beitelovgjevninga førte ikke til noen lovendring. Utredningen har som sådan mindre rettskildemessig verdi. Nevnes kan også at Austenå, op.cit. s. 24 påpeker at lovutvalget kom med temmelig radikale forslag, der dyreeiers ansvar for skade dyra gjorde på annen manns grunn skulle bygge på skyldansvar og ikke objektivt ansvar. Dette liknet i følge Austenå prinsippet fra før 1860 der eier av dyrka jord fikk hovedansvaret for å verne jorda si. Et annet nytt forslag var det utvalget kalte «streifbeiteretten».

10) Lov 2. juni 1883 angaande Lapperne i de forende Kongeriger Norge og Sverige, i kraft 1. januar 1884. De eldste reglene om ansvar for reinskade finner vi i Første codicill og Tillæg til Grendse-Tractaten imellem kongerigerne Norge og Sverrig Lapperne betreffende 2. okt. 1751 (Lappekodisillen). 
Ansvaret omfattet ikke bare det vi i dag betegner som innmark, men også utengsslåtter som var inngjerdet eller år om annet ble brukt til slått og framsto som slåtteland. Paragrafen ga også regler om fellesansvar, hvor samtlige reineiere innen distriktet ble holdt ansvarlige for skaden. ${ }^{11)}$ Reineier kunne også stilles til ansvar der reinen lovlig kunne beite i utmark, hvis «Jordens Eier eller Bruger derved kommer til at savne fornødent Bete for sit Bofæ».

Selv om både felleslappeloven av 1883 og lov om jords fredning av 1860 statuerte et objektivt erstatningsansvar for beiteskade, gjorde gjerdeholdstvangen ansvaret langt lettere å bære for bufeholderen enn for reineieren. Mangelfullt gjerdehold hos jorddyrkeren kunne lede til bortfall av erstatning hvis bufe forårsaket skaden. ${ }^{12)}$ Noen regel om reduksjon i ansvar ved manglende gjerdehold ble ikke gjort gjeldende etter felleslappeloven, som endog bestemte at grunneiers fôrbehov i utmark kunne være avgjørende for reineiers ansvar.

Ulikheten i husdyreiers og reineiers ansvar ble påpekt av to justisråder i Högsta domstolen i Sverige under høringen av den felles svensk-norske loven. De uttalte at forslaget på beste måte hadde søkt å sørge for at de fastboende hadde krav på skadeerstatning, samtidig som det ikke på noen måte hadde søkt å lette samenes omhyggelige plikt til å vokte sine rein for å unngå ansvar for skade: «Idet Forslaget af Lapperne fordrer en nøiagtigere Bevogtning af deres Rener, end de under de givne Forudsætninger kunne overkomme, og paalægger den ene Lap at bøde for den anden, maaler det den Fastboendes og Nomadens Ret med ulige Maal og afviger saameget fra Lovgivningsprinciper, som i Sverige fra Alders Tid har været gjældende, at jeg for min Del vedblivende maa fraraade dets antagelse - trods de Forbedringer, som det efterhaanden har undergaaet.» ${ }^{13)}$

Felleslappeloven omfattet ikke Finnmark. Av Utkast til Lov om rendriften, utarbeidet av riksadvokat P. Kjerschow i 1922, framgår det at det på dette tidspunkt ikke eksisterte noen lovregler om reineiernes erstatningsansvar i Finnmark. Et av målene med ny reindriftslov ble dermed å regulere ansvaret for skade forårsaket av rein i fylket. Ved lov 12. mai 1933 nr. 3 om reindriften ble objektivt fellesansvar for reinskade innført i

11) I $\S 6$ ble det åpnet for distriktsinndeling, noe som var en forutsetning for å kunne gjøre fellesansvaret gjeldede.

12) Hærem, op.cit. s. 13 påpeker at «også jorddyrkeren hadde oppfordring til å oppfylle sin del av gjerdeplikten. Hadde hans forsømmelse på dette punkt medført at hest eller storfe kom inn og gjorde skade på hans eiendom, kunne han ikke kreve noen erstatning hvis naboen hadde oppfylt gjerdeplikt (§ 24)». Av samme lov § 23 annet punktum framgår det at ansvaret for sau i stor grad var det samme som for hest og storfe.

13) Oth. Prp. No 2 (1882) ang. Lov om Lapperne i De forenede Riger s. 120 sp. 1. Uttalelse fra Justitsraad Carleson med tiltredelse fra Justitsraad Olivecrona. 
Finnmark. Reindriftens fremtredende økonomiske betydning som næring i fylket førte likevel til at lovgivningen fikk en annen utforming her enn i det øvrige landet når det gjaldt jordbrukets vern for reinskade. ${ }^{14)}$ Erstatningsreglene i felleslappeloven, som i hovedsak ble videreført, og som må sies å statuere et langt strengere ansvar enn det som gjaldt for bufeholdere, ble således ikke gjort gjeldende for finnmarksreindriften. Loven ble utformet med geografisk differensierte regler for skadeerstatning, hvor reindriftsutøvere i Finnmark ble stilt i en gunstigere situasjon enn reineiere for øvrig.

Sør for Troms var de reindriftsberettigede som hovedregel objektivt ansvarlig for enhver reinskade på innmark, åker, eng, skog, slåtteland, multebærland, torv til tørring og avskåret avling, jf. reindriftsloven av $1933 \$ 39$ første ledd. ${ }^{15)}$ De var også ansvarlig for skade på uinngjerdet «havnegang» for så vidt eier eller bruker kom til å savne «fornødent beite for det i havnegangen beitende bufe». De samme reglene gjaldt i Troms, med unntak av ansvarsfrihet for skader på «havnegang» fram til 15. juni. Ansvaret ble gradvis utvidet fram til 7. juli. Etter denne dato gjaldt ingen ansvarsbegrensning.

I Finnmark var reineierne kun erstatningspliktig for skade på åker og eng som var innhegnet med "gjerde som fredet mot rein", eller når disse lå innen en avstand av to kilometer fra jordbrukerens bopel $(\$ 41)$. Skadeansvaret for slåtteland utenfor gårdens innmark var svært begrenset og gjaldt kun slåtter som var inngjerdet med gjerde som fredet for rein, eller, hvis skade var voldt etter 24. juni, innen en avstand av to kilometer fra jordbrukers bopel. Jordbrukers nødvendige havnegang var på liknende måte gitt vern mot beiteskade på samme vilkår. I motsetning til i fylkene sør for Finnmark, hvor fritak for erstatningsansvar under flytting kun gjaldt flyttevei, var samene under flytting ikke ansvarlig for skade rein forårsaket på uinnhegnet åker, eng, slåtteland eller sætervoll som lå i nærheten av flyttevegen, med mindre skaden skyldes forsett eller grov uaktsomhet, jf. $\$ 41$ annet ledd.

Foruten reindriftslovens regler om differensierte erstatningsregler ble det i medhold av jordsalgsloven av 1902 tatt inn ansvarsfrihetsklausuler på jord som ble avhendet fra staten til private. Disse klausulene fastsatte et mindre tyngende ansvar for beiteskade på rydningsbruk. ${ }^{16)}$ I Kjerschows lovutkast ble det lagt til grunn at rettspraksis ga liten vei-

14) I Utkast til Lov om rendriften s. 117-118 het det: «Den betydelige økonomiske interesse, som således knytter sig til rendriften, ... må medføre, at lovgivningen her må anvende en nogen annen målestok ved vurderingen og bestemmelsen av denne næringsgrens forhold til jordbruksnæringen, dette så meget mere som denne siste står og må stå på et betydelig lavere trin av utvikling og betydning i dette fylket enn i rikets øvrige fylker.»

15) Det ble gjort unntak for skade på slåtteland voldt i tiden utenfor vekstsesongen, og for skade på flytteveg, med mindre skaden var voldt ved at de uten nødvendighet hadde latt dyrene spre seg, jf. § 39 tredje ledd. 
ledning om hvordan denne bestemmelse var å forstå, samtidig som det ble vist til at det fra reindriftens side var hevdet at klausulene ga uttrykk for «festnet sedvanerett». ${ }^{17)}$

Senere rettspraksis fastslo at ansvarsfrihetsklausulene måtte vike for erstatningsreglene i reindriftsloven, jf. i Rt. 1955 s. 184. På tross av ansvarsreglene i reindriftsloven fortsatte jordsalgsmyndighetene i Finnmark å utstede skjøter med ansvarsfrihetsklausul. Betydningen av klausul i skjøtet utstedet etter ikrafttreden av reinl. av 1933, ble prøvd av kjæremålsutvalget i en kjennelse gjengitt i Rt. 1956 s. 441. Her kom kjæremålsutvalget, til tross for at det førte til forskjellige regler for reindriftssamenes erstatningsansvar avhengig av tidspunkt for skjøtets utstedelse, til at meningen var å gi reindriftsutøveren den ansvarsfrihet klausulen innrømmet han. ${ }^{18)}$

Under arbeidet som ledet fram til reindriftsloven av 1978 oppsto det uenighet om en rekke forhold, herunder reglene om erstatningsansvar. ${ }^{19)}$ Kort fortalt endte det med at reglene om dette i 1933-loven i hovedsak ble videreført, samtidig som de geografisk differensierte erstatningsreglene ble fjernet. Etter 1978-loven er reineier pålagt vokteplikt, i loven kalt driveplikt, jf. reinl. $\$ 20$ første ledd, hvor det heter at reinen skal til enhver tid være under forsvarlig kontroll på lovlig beite. Brudd på den kan lede til erstatningsansvar. Reglene om ansvar for skade forårsaket av rein finner vi i reinl. $\$ \$ 25-26$. I likhet med $\$ 7$ i beiteloven statuerer reindriftsloven et objektivt ansvar. Det er gjort unntak fra det objektive ansvaret hvis skaden skjer under lovlig flytting eller på annet område hvor reinen lovlig kan oppholde seg, jf. $\$ 26$ første ledd. Men i motsetning til grunneier har ikke reineier rett til for egen regning å føre opp gjerde etter ggl. $\$ 6$. Det er dessuten lagt til grunn at reineier ikke kan kreve gjerdehold av grunneier slik bufeholder kan i medhold av ggl. \$11, da reinl. $\$ 26$ tredje og fjerde ledd er «serlege rettshøve» som går foran grannegjerdeloven, jf. ggl.

16) I reglement av 7. juni 1902 ble det i § 1 litra b fastsatt at «[h]vis jorden ligger i nærheten av fjellfinners ferdselsveier, og den ikke holdes forsvarlig innhegnet, skal fjellfinnene være uten ansvar, om deres hjorder gjør skade derpå, med mindre forsettelighet eller grov uaktsomhet kan legges vedkommende til last». Også eldre lovgivning hadde liknende regler, se Sverre Tønnesen, Retten til jorden i Finnmark(Bergen 1972) s. 291. Disse var mindre vidtrekkende, idet de primært omfattet forpaktede utmarksslåtter, og ikke den solgte jorden, altså det som var forutsatt å bli nyetablerte gårders hjemmemark.

17) Utkast til Lov om rendriften utarbeidet av riksadvokat P. Kjerschow s. 113 sp. 2.

18) I RG 1984 S. 524 kom Vardø herredsrett til at ansvarsklausulene på to parseller etablert hhv. i 1937 og 1948, altså etter ikrafttreden av 1933-loven, ikke hadde betydning for erstatningsansvaret. Retten la avgjørende vekt på forarbeidet til reindriftsloven av 1978 om at loven uttømmende regulerte retten til å drive reindrift.

19) I Innst. fra Reindriftslovkomitéen framlagt i 1966 ble det bl.a. foreslått å redusere det solidariske erstatningsansvaret. Det ble også foreslått at skade på innmark og kulturbeite ikke skulle være gjenstand for erstatningsansvar «dersom innmarken eller kulturbeitet ikke er inngjerdet slik at gjerdet freder for rein». Se også note 21. 
$\$ 1 .^{20)}$ Noen analog regel til beiteloven $₫ 7$ annet ledd hvor skadeansvaret kan bli redusert eller falle bort hvis skadelidte forsømmer sin gjerdeplikt eller annet, passer dermed ikke.

Rettspraksis viser da også at fravær av tiltak fra grunneiers side for å redusere skaderisiko, slik som inngjerding, ikke har fătt betydning for erstatningsansvaret. Praksis viser dessuten at reglene om skadelidtes medvirkning og lemping av ansvar både etter de generelle reglene om medvirkning ${ }^{21)}$ og reindriftsloven er vurdert, men at domstolene har satt svært høye krav for bortfall eller reduksjon av erstatningsansvaret.

I en avgjørelse i Rt. 1967 s. 1265 (etter reindriftsloven av 1933) hadde staten tilbudt seg å stille til disposisjon stolper og tråd mot at grunneierne satte opp gjerdet og påtok seg å vedlikeholde det for å bidra til løsning av en konflikt i mellom reineiere og grunneiere i Nord-Troms. Grunneierne aksepterte ikke tilbudet. Lyngen herredsrett idømte reineierne å erstatte den skade deres rein hadde forårsaket. At staten hadde tilbudt seg å bidra til inngjerding, ble ikke vektlagt. Reineierne påkjærte avgjørelsen og anførte «at selv om reindriftslovens $\$ 39$ i sitt utgangspunkt ikke har pålagt jordbrukerne i Tromsø noen alminnelige plikter når det gjelder gjerdehold, så har det ikke vært meningen å trekke et så klart skille mellom gjerdeplikten i Finnmark og Troms fylke at ikke de tilbud og forhandlinger om oppsetting av gjerde - med derpå følgende avslag av ankemotpartene - vil medføre at straffelovens ikrafttredelseslov $\$ 25$, 2. ledd [nå avløst av lov 13 . juni $1969 \mathrm{nr}$. 26 om skadeserstatning $\$ 5-1$ ], fritar reineierne for erstatningsplikt». Høyesteretts kjæremålsutvalg forkastet enstemmig kjæremålet, og var i likhet med herredsretten av den oppfatning at reindriftsloven $\$ 39$, jfr. $\$ 40$, måtte forstås slik at grunneiere i Troms ikke har noen plikt til å holde gjerde for å beskytte seg mot skade fra rein.

At grunneier dyrker opp områder hvor reinen er vant til å finne sitt beite, har heller ikke blitt betraktet som medvirkning, aksept av risiko eller som annen grunn for lem-

20) Se Kirsti Strøm Bull, Studier i reindriftsrett (Oslo 1997) s. 111. Se også Bjarne Danielsen, Gjerdeloven (Oslo 1962) s. 11 som viser til lov om reindriften 12. mai 1933 og lov 29. mai 1953 om konvensjon mellom Norge og Finland av 18. mars 1952 om bygging og vedlikehold av reingjerder og andre tiltak for å hindre at rein kommer over grensen mellom de to riker. De forhold Danielsen her sikter til er ikke slike grannegjerdeloven regulerer.

21) Lov 22. mai $1902 \mathrm{nr}$. 11 om den almindelige borgerlige Straffelovs Ikrafttræden kapittel 3, avløst av lov 13. juni 1969 nr. 26 om skadeserstatning. Det må i den sammenheng nevnes at «lempingsreglene» i reinl. § 26 første ledd primært er ment å redusere det objektive ansvar under flytting og på utmarksområder som omfattes av erstatningsansvar. De er således ikke lempingsregler i vanlig forstand som skulle komme i stedet for de alminnelige lempingsregler, slik også Kirsti Strøm Bull, Studier i reindriftsrett (Oslo 1997) s. 113. Det må imidlertid sies at relevansen av skadeerstatningsloven $\S 5^{-1}$ kan synes noe perifer i forhold til ansvar for beiteskade, da ansvaret ubetinget er lagt på reineier så sant vedkommende ikke har krevd skjønn etter reinl. § 26 tredje ledd, noe jeg kommer tilbake til. 
ping i erstatningsreglene. I en kjennelse i Rt. 1975 s. 796, som også ble behandlet etter tidligere reindriftslov, kom Høyesteretts kjæremålsutvalg til at selv om beiteskaden var påført et nylig oppdyrket område som tidligere hadde vært reinbeite, gav dette ikke grunnlag for en innskrenkende tolking av erstatningsregler i reindriftsloven (av 1933). Utvalget uttalte at grunneier ikke hadde plikt til å sette opp eller vedlikeholde gjerde rundt innmarken til fredning mot rein, og at skaden dermed var klart omfattet av lovens bokstav: «Etter utvalgets mening må det også når det gjelder nydyrkingsfelter lovendring til for at skade voldt på område som ikke er innhegnet med gjerde som freder mot rein, skal være unntatt fra lovens regler.» ${ }^{22)}$ For øvrig nevnes det at Høyesterett, obiter dictum, frambar et liknende syn i Rt. 1975 s. 1029, hvor det het: «Gjennom nydyrking og driftsomlegging kan private grunneiere treffe tiltak som flyttsamene må avfinne seg med og må innrette sin reindrift etter.»

I RG 1984 s. 524 la Vardø herredsrett til grunn at verken klausul i skjøtet eller alminnelige rettsprinsipper om lempning av erstatningsansvaret kunne føre til at reineiernes objektive ansvar for skade forårsaket av rein på innmark oppdyrket i reinbeiteområde kunne fravikes. Retten uttalte bl.a. at det ikke var grunnlag for å pålegge eier eller bruker av de to parsellene en plikt til å verne mot rein gjennom oppføring av gjerder eller etablering av vakthold e.l. ${ }^{23)}$

I en dom avsagt av Frostating lagmannsrett 10. des. 2002 (LF-2002-127) ble manglende gjerdehold ikke betraktet som medvirkning fra skadelidtes side. Frostating jordskifteoverrett hadde i likhet med underinstansen pålagt reineierne å erstatte beiteskade. Skjønnet ble anket til Frostating lagmannsrett når det gjaldt rettsanvendelsen. Angående skadelidtes medvirkning uttalte lagmannsretten at jordskifteoverretten, bl.a. under henvisning til Rt. 1967 s. 1285, synes å ha lagt avgjørende vekt på at grunneierne ikke har gjerdeplikt etter reindriftsloven, og at det da ikke representerte erstatningsreduserende medvirkning å unnlate å sette opp gjerde. Lagmannsretten anså

22) I Innst. O. nr. 98 (1976-77) Innstilling fra landbrukskomiteen om lov om reindrift s. 8 sp. 2 framgår det at landbrukskomiteens formannen gjorde framlegg om tillegg til forslaget til reinl. § 26 første ledd: «Erstatningsansvar uten skyld gjelder ikke for frittliggende nydyrkningsområder eller kulturbeiter som ikke er omgitt av gjerde som freder effektivt for rein.» Behandling av loven ble utsatt, noe som ledet til at departementet fremmet nytt lovforslag, Ot.prp. nr. 24 (1977-78) Om lov om reindrift, med påfølgende ny innstilling fra Landbrukskomiteen, Innst. O. nr. 37 (1977-78). Her er forslaget utelatt.

23) At grunneier ikke hadde gjerdeplikt, ble grunngitt gjennom en analogisk anvendelse av beiteloven $\S 1$ hvor det het at eier av husdyr skal sørge for at husdyra ikke kommer inn på områder der han ikke har rett til å la dem være, og at han er erstatningsansvarlig for skade som dyra volder i slike områder. 
dette som korrekt rettsanvendelse og viste bl.a. til Ot.prp. nr. 9 (1976-1977) s. 45, hvor det fremgikk at forslag om at inngjerding av innmark eller kulturbeite skulle være en forutsetning for å oppnå erstatning, ble vurdert, men ikke tatt med i reindriftsloven . Søknad om tillatelse til å bringe anken inn for Høyesterett uavhengig av verdigrense ble avslått, jf. HR-2003-00307-1.

\subsection{Særlig om rett til å føre opp gjerde og fordeling av kostnad ved dette}

Som vi har sett kan bufeholder som utgangspunkt kreve at grunneier skal ta del i gjerdehold, jf. ggl. $\$ \$ 7$ og 11. Forsømmelse av dette fra grunneiers side kan lede til reduksjon og bortfall av rett til erstatning. Den største forskjellen i forhold til reineiers erstatningsansvar er at grunneier ikke har noen slik gjerdeplikt i forhold til rein. Reineier har heller ikke rett til for egen kostnad å føre opp gjerde slik granne har mot granneeiendom, jf. ggl. $\$ 6$.

Reindriftsloven har imidlertid egne regler om gjerdehold, noe som vi har sett er antatt å være et særlig rettsforhold som tilsier at grannegjerdelovens bestemmelser ikke omfatter reindriften. Disse reglene, som er gitt i reinl. $\$ 26$ tredje og fjerde ledd, innebærer at reineier, i mangel av minnelig overenskomst, gjennom skjønn ved jordskifteretten kan få avgjort om han har adgang til å føre opp gjerde til støtte for sin driveplikt, jf. reinl. $\$ 26$ tredje ledd. Mellom granner eller mellom bruksrettshaver og eier skal gjerdeholdet etter grannegjerdeloven som utgangspunkt deles likt der gjerdeplikt foreligger. Hvis dette er urimelig, kan gjerdeholdet deles etter nytte fastsatt ved skjønn. Reindriftsloven $\$ 26$ tredje ledd har en $i k k e$ ulik fordelingsregel hvor grunneier ved skjønn kan pålegges å bære en rimelig del av kostnadene med oppføring og vedlikehold av det gjerdet reineier gjennom skjønn kan gis adgang til å føre opp. Grunneier skal da pålegges kostnad etter den nytte han har av tiltaket.

I relasjon til nyttebegrepet må det være adgang til å anta at nytten av gjerdet for en jorddyrker ikke er vesensforskjellig om gjerdet freder for rein eller bufe. Som vi har sett av forarbeidene til grannegjerdeloven og praksis, kan ikke ansvaret uten videre alene legges på dyreeieren. Det som her er av særlig interesse, og som trolig ikke er tilstrekkelig påaktet, er forarbeidsuttalelsen om at «skjønnet skal ta i betraktning om grunneieren fra tidligere har hatt noen gjerdeplikt og om oppføring av gjerde etter gjeldende lov [av 1933] har vært et vilkår for erstatning for skade voldt av rein ...» ${ }^{24)}$ Dette synes å peke på at reineier gjennom skjønn skal kunne få videreført den gjerdeplikt grunneier hadde etter reinl. av 1933, etter klausuler i medhold av annen lovgivning og eventuelt

24) Ot.prp. nr. 9 (1976-77) s. 63 sp. 2. At gjerdet kan ha andre formål f.eks. frede for bufe skal også vektlegges. 
etter sedvanerett. ${ }^{25)}$ At departementet også pekte på at bestemmelsen «i en viss grad vil kunne virke som et korrektiv til at gjeldende lovs differensierte erstatningsregler faller bort», underbygger dette.

Bestemmelsen i reinl. $\$ 26$ tredje ledd innebærer altså at reineier gjennom krav om skjønn kan få rett til å føre opp gjerde til sikring mot erstatningsansvar, og at rimelig andel av kostnad ved dette gjerdet kan pålegges grunneier etter nytte. Til grunn for nyttevurderingen kan ligge (1) den «generelle» nytte jordeier er vurdert å ha av at gjerdet freder for beitedyr, jf. Rådsegn 1 s. 13, (2) annen nytte uavhengig av at gjerdet stenger for rein, og (3) den nytte grunneier har hatt av gjerde etter tidligere gjerdeplikt i medhold av lov eller sedvanerett. ${ }^{26)}$ Men - det må altså kreves skjønn før disse reglene kan praktiseres.

\section{EN SAMMENLIKNING AV SKADEANSVAR OG}

\section{GJERDEHOLDSREGLER FOR REINEIERE OG BUFEHOLDERE}

3.1 De geografisk differensierte erstatningsreglene erstattes av regler om gjerdeskjønn Foran har vi sett at de geografisk differensierte erstatningsreglene som i prinsippet stilte reineiere i Finnmark nærmere opp mot bufeholdere når det gjaldt erstatningsansvar for skade forårsaket av beitedyr, ikke ble videreført i reindriftsloven av 1978. Dette påla etter alt å dømme reineiere i Finnmark et tyngre erstatningsansvar. Kirsti Strøm Bullhar påpekt at hvis en sammenlikner reindriftsloven av 1933 med reglene i dagens reindriftslov, vil man oppdage at det har skjedd en betydelig skjerping av reindriftsutøvernes erstatningsansvar: «I dag er all innmark vernet gjennom objektive ansvarsregler uansett om innmarken er inngjerdet eller ikke og uavhengig av avstanden til gårdbrukerens bopel og uavhengig av årstid.» Samtidig påpeker hun også at denne skjerpingen av erstatningsansvaret ikke kom til uttrykk i lovens forarbeider, og viser til at departementet synes å gi uttrykk for at reglene innebar visse lempinger i erstatningsplikten i forhold til tidligere regler. ${ }^{27)}$

Bakgrunnen for fjerningen av de geografisk differensierte reglene kan synes å være behandlet etter måten lett i forarbeidet. Det het at «[d]e spesielle hensyn som gjeldende lov har ment å tilgodese ved de ulike ansvarsreglene for henholdsvis Finnmark fylke,

25) Se oppfatningen om «festnet sedvanerett» knyttet til dette i punkt 2.2 (note 17).

26) I relasjon til bufe har domstolene ved flere anledninger vektlagt at det gjennom sedvane eller alders tids bruk var etablert gjerdeplikt, se RG 1972 s. 8 (Frostating), RG 1972 s. 715 (Hålogaland) og RG 1985 S. 330 (Gjøvik). At slik sedvanerett også foreligger i relasjon til reindriften kan knapt sies å være usannsynlig, jf. også 3.3 under.

27) Bull, Studier i reindriftsretts. 122. 
Troms fylke og resten av landet, er det etter departementets forståelse ikke grunn til særskilt å innarbeide i den nye lov». ${ }^{28)}$ En må imidlertid merke seg at som et korrektiv til at de differensierte erstatningsregler falt bort, foreslo departementet samme plass i stedet adgang til å få avgjort ved skjønn om det skal være anledning til å sette opp gjerde til støtte for reineiers vokteplikt. Som vi har sett forutsatte departementet «at skjønnet ved denne vurdering også skal ta i betraktning om grunneier fra tidligere har hatt noen gjerdeplikt og om oppføring av gjerde etter gjeldende lov har vært et vilkår for erstatning for skade voldt av rein ...».

Bestemmelsen har imidlertid ikke ledet til at det er avholdt skjønn hvor tidligere gjerdeplikts betydning for gjerdeholdsfordelingen er vurdert. Ut fra den praksis jeg har hatt anledning til å gjennomgå, har jeg ikke funnet noen skjønn avholdt etter reinl. $\$ 26$ tredje ledd. ${ }^{29)}$

Bull har påpekt at Landbruksdepartementets framstilling av de nye erstatningsreglene for reinskade innebar at Stortinget ble gitt et uriktig bilde av reglene som innebar at Stortinget var «ikke klar over at man gjennom 1978-loven påla reindriften et strengere erstatningsansvar enn tidligere». ${ }^{30)}$ Forarbeidet til bestemmelsen om reineiers adgang til å føre opp gjerde til sikring mot erstatningsansvar og reglene om fordeling av kostnad ved dette, jf. reinl. $\$ 26$ tredje ledd, synes etter mitt skjønn ikke å underbygge dette, men peker på at lovgiver har åpnet for en mer nyansert praktisering av erstatningsansvaret enn det som er dagens realitet. Departementets uttalelse i Ot.prp. nr. 9 (1976-77) s. 63 sp. 2 kan tyde på at det så for seg at gjerdeskjønn for å få vurdert adgang til å føre opp gjerde til støtte for reineiers vokteplikt, og hvor grunneier ble pålagt del av gjerdeholdet, skulle bli en levende rettsregel, som også kunne lede til at gjerdehold ble videreført der det tidligere hadde vært regler om det.

Departementet foreslo at det ble satt som vilkår at reineier eller reinbeitedistrikt måtte kreve skjønn for å få fastslått adgang til gjerdehold, og hvordan dette skulle deles. Regelen om gjerdeholdsdeling var langt på veg i samsvar med reglene som gjaldt for bufeholdere der likedeling falt urimelig. Derimot avvek regelen om at adgang til å føre

28) I Ot.prp. nr. 9 (1976-77) s. 63 sp. 2.

29) I «Oppfatningen av samiske reinbeiterettigheter som «tålt bruk» i jordskiftesaker», Lov og rett, 2005 S. 601-619 har jeg vist til at det kun er avholdt tre skjønn (samt et overskjønn) etter at lov nr. 8/1996 trådte i kraft, hvorav to (tre) gjaldt erstatning etter reinl. § 26. Ingen gjaldt adgang til og fordeling av gjerdehold. Etter dette er enda et erstatningsskjønn avhjemlet (sak 7/2004 for Finnmark jordskifterett). Jeg har ikke hatt adgang til å undersøke de skjønn som kan være avholdt fra 1. januar 1979 til 1. juli 1996 da lensmannsskjønn var rett instans for slike saker.

30) Bull, Studier i reindriftsrett s. 122-123. Dette mener hun må få betydning for reglenes anvendelse. 
opp gjerde for egen kostnad er betinget av skjønn, fra grannegjerdelovens regler. Selv med den sistnevnte forskjell burde etter min mening skjønn være mer aktivt nyttet av reineiere. Dette må særlig gjelde i Finnmark, der gjerdehold tidligere i mange sammenhenger har vært et vilkår for reineiers erstatningsansvar. Slik lovgiver har ment at nytte skal vurderes (se punkt 2.3), burde skjønn kunne lede til en rimelig fordeling av gjerdeholdskostnad mellom reineier og grunneier.

Ut fra dette kan det vanskelig hevdes at departementet mente at den nye loven skulle lede til ansvarsskjerpelse i Finnmark. Følgene av å ikke videreføre de differensierte erstatningsreglene synes dermed å ha blitt en annen enn forutsatt. At erstatningsansvaret fortsatt er vesentlig strengere for reineiere enn for bufeholdere, slik påpekt av Reindriftslovutvalget, og at det for reineiere i Finnmark framstår som skjerpet gjennom 1978-loven, skyldes heller at adgangen til å kreve skjønn for å få fastsatt gjerdeholdsadgang og kostnadsdeling for slikt gjerde ikke er nyttet. Om det skyldes oppfatninger om at bestemmelsene ikke funger i praksis, slik reindriftsparten ga uttrykk for i anke på overskjønn i sak LF-2002-127 for Frostating lagmannsrett (omtalt i punkt 2.2), om det kan skyldes generell mistillit til rettsvesenet eller instansene som skal behandle slike saker, eller om det kan være sider ved den reindriftssamiske kulturen som tilsier at slik måte å fordele kostnad og ansvar på virker fremmed, burde være gjenstand for oppmerksomhet. På dette formatet har jeg ikke mulighet til å gå inn på det.

Om det entydig er slik at reinl. $\$ 26$ tredje ledd er et særlig rettsforhold som utelukker at reineier kan være «brukar» etter ggl. $\$ 11$, burde kanskje også vies oppmerksomhet. Forarbeidene til loven peker på at en med «serlege rettshøve» sikter til rett stiftet på særskilt grunnlag i motsetning til alminnelig lovgivning. ${ }^{31)}$ Derimot kan det fremholdes at prioritetsreglene for løsing av motstrid slik som lex posterior og lex spesialis leder til at reinl. $\$ 26$ setter grannegjerdelovens regler til side. Det må imidlertid kunne reises spørsmål om reindriftsloven fullt ut regulerer de forhold ggl. $\$ 11$ er ment å regulere, særlig med henblikk på hva situasjonen er hvis reineier ikke nytter sin mulighet til å kreve skjønn i medhold av reinl. $\$ 26$ tredje ledd. Etter det jeg kan se, har disse spørsmålene ikke vært prøvd av domstolene. Formatet på arbeidet gjør at jeg ikke kan gå videre inn på dette her.

\subsection{Noen betraktninger de lege ferenda sett i relasjon til lovrevisjonen}

Erstatningsansvaret for reineiere, i alle fall i Finnmark, og trolig også i det øvrige landet, kunne ha vært mer likt ansvaret for bufeholdere hvis den «sovende bestemmelsen» om skjønn for å få fastsatt gjerdehold til støtte for vokteplikten hadde vært anvendt. For å

31) Se hhv. Rådsegn 1 s. 16 sp. 1 og Ot.prp. nr. 18 (1959) s. 11. 
«vekke» denne bestemmelsen og slik sett muliggjøre en praksis mer i samsvar med beitelovgivningen, bør det etter mitt skjønn gjøres visse lovmessige endringer i reindriftsloven.

En nærliggende endring kan være at reineier i medhold av sin bruksrett gis rett til oppføring av gjerde på visse vilkår, f.eks. der beiterett støter mot innmark, uten krav om forutgående skjønn. Rettsutviklingen, hvor reindriftssamers bruksretter er blitt mer likestilte med andre bruksrettigheter av privat karakter, burde gjøre det aktuelt å vurdere innført gjerdeplikt med korresponderende kostnadsdeling etter nytte, der både bruksrettshaver og grunneier har nytte av gjerdet, slik ggl. $\$ 11$ foreskriver for forhold mellom jordeier og bufeholdere. Gjerdeplikt er en forutsetning for at det skal være meningsfylt å se reglene i reinl. $\$ \$ 25$ og 26 i relasjon til de alminnelige erstatningsrettslige regler om skadelidtes medvirkning i skadeerstatningsloven $₫ 5-1$, slik foreslått av Reindriftslovutvalget NOU 2001:35 s. 183. Også i reindriftslovgivningen kan utgangspunktet være likedeling av kostnad mellom reineier og jordeier, men slik at urimeligheter kan kreves korrigert ved skjønn. Rettspraksis viser som vi har sett, at bufeholder med beiterett både har adgang til å føre opp gjerde og kan kreve dette av grunneier. En annen tilnærming, som muligens kan innebære det samme, er at den usikkerhet som måtte foreligge i relasjon til om dagens ggl. $\$ 11$ kan gjøres gjeldende i forhold mellom reineiere og grunneiere, avklares av lovgiver.

Et annet utgangspunkt kan være at det settes krav om at minnelig gjerdeordning og/ eller skjønnsregelen i reinl. $\$ 26$ tredje ledd skal være prøvd før erstatningskrav overfor reineier kan fremmes. Det må da åpnes for at så vel grunneier som reineier kan kreve slikt skjønn.

Som en avslutning kan det nevnes at Reindriftslovkomiteen foreslo en harmonisering av regelverket mellom bufeholders og reineiers ansvar for skade i 1966. Forslaget møtte den gang sterk motstand. I dag, 40 år senere, har den norske stat erkjent at landet er grunnet på to folks territorier. At reindrift er en like framtidsrettet, og i sine områder, like viktig næring for landet som jordbruket, tilsier at reindriftslovgivningen bør utformes slik at lovgivning og rettspraksis harmoniseres opp mot de regler og den praksis som gjelder for bufeholders ansvar for skade han eller hennes dyr forårsaker. 